\title{
Transatlantica
}

Revue d'études américaines. American Studies Journal

\section{Creating the Child Audience: Media and the Invention of Modern American Childhood}

\section{Thibaut Clément}

\section{(2) OpenEdition}

\section{Journals}

Electronic version

URL: https://journals.openedition.org/transatlantica/15136

DOI: $10.4000 /$ transatlantica. 15136

ISSN: $1765-2766$

\section{Publisher}

Association française d'Etudes Américaines (AFEA)

Electronic reference

Thibaut Clément, "Creating the Child Audience: Media and the Invention of Modern American Childhood", Transatlantica [Online], 2 | 2019, Online since 01 October 2020, connection on 01 February 2023. URL: http://journals.openedition.org/transatlantica/15136 ; DOI: https://doi.org/10.4000/ transatlantica. 15136

This text was automatically generated on 1 February 2023.

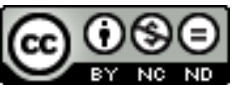

Creative Commons - Attribution-NonCommercial-NoDerivatives 4.0 International - CC BY-NC-ND 4.0 https://creativecommons.org/licenses/by-nc-nd/4.0/ 


\title{
Creating the Child Audience: Media and the Invention of Modern American Childhood
}

\author{
Thibaut Clément
}

1 "Won't somebody please think of the children?," Simpsons character Helen Lovejoy famously asks in one of pop culture's most enduring caricatures of the political class's moral posturing and often superficial concern for child welfare ("Much Apu about Nothing" 05:53-05:58). Breaking from such pronouncements on children's perennial vulnerability, new childhood studies effectively shifted away from earlier notions of a "universal child" (marked by biological, cultural, and psychological universals, cutting across all cultural and social groups) to the idea of childhood as a social construct, contingent on historically and culturally situated realities. Starting in the 1980s, researchers have thus increasingly placed emphasis on children as "agents" and "beings" in their own right, whereas before they were conceptualized as the "passive subjects of structural determinations" and "human becomings"-i.e. human adults in the making (James and Prout, 1990 4; Qvotrup, 1985 132).

2 In the United States, modern attitudes to childhood as a realm separate from the adult world date back to progressivism, whose gradual "sentimentalization" (Zelizer) of childhood resulted in part from Romanticism or Lockean conceptions of children as blank slates-in other words, as innocent and impressionable. New attitudes toward children also originated in the social, cultural, and economic developments of the late nineteenth century, with the gradual eradication of child labor, changing patterns in family life, and women's social roles, as well as growing concern for the successful socialization of immigrant or maladjusted children, notably through universal school enrollment. In the process, the values of the middle class came to define the standard for what childhood should be, suppressing non-conforming groups as legitimate models in the process. The institutionalization of children through schooling may thus in part be understood as an attempt to separate children from the influence of adults in their lives and bring them more directly under the supervision of society-as was 
especially the case for immigrant or vagrant children in the mid to late nineteenth century.

3 The development of such constructs of childhood was reliant on the media industry. An emerging mass culture targeting children harnessed new communication technologies to reach ever larger print, broadcast, and now digital audiences. The demarcation of the adult and child's worlds conversely opened new avenues for the creation of a specific market-for children-when, starting in the 1920s, production began to outpace consumption and manufacturers set out to search for new sales opportunities. This, in turn, placed children in the role of agents more or less directly involved in the purchase and consumption of products specifically geared toward them, the media being a major promoter of consumer culture, more specifically, of corporations and their products. In one especially iconic example, Disney was quick to capitalize on Mickey Mouse's immense popularity and exploit its character's licensing and merchandising potential farther than any other studio before. Critical to establishing the nexus between Disney films, child audiences, and merchandise was the development of the Depression-era Mickey Mouse Clubs: developed with toy manufacturers, theater operators, and department store owners, the scheme essentially aimed to ease the transition from the theater to the department stores and tie together the consumption of Disney films and toys, in hopes to boost audiences and sales for both (DeCordova).

4 This issue of Transatlantica sets out to examine how, in the process of creating new audiences for their products, child-centric media helped craft a homogenizing vision of childhood especially compatible with media consumption. As a result, in the course of the late nineteenth and twentieth centuries, the media made themselves the vehicle of adult norms and expectations about children's tastes, behaviors, and development. In the process, producers have aimed to either pander to existing tastes and behaviors, or shape those to ideal standards, some civic-minded (with an emphasis on social adjustment, character-building, or good citizenship), some commercial, and others both at once.

5 To reprise observations made by Allison James, James Prout, and David Buckingham, the media have come to work as a Foucauldian "regime of truth" (James and Prout, 1990 23): as they "naturalize assumptions about how children are and should be" (Buckingham 7), children's media represent a specific transaction between adults and children, namely an attempt to imprint a specific self-image on children and encourage desirable behaviors. Drawing from analyses of museum art-education initiatives as well as film, television, and print media, this issue focuses on how children's cultural industries provide an especially illuminating case of how producers make inferences about audiences and intend to understand as well as affect their behaviors. Conversely, the study of children's media and cultural industries sheds light on childhood's socially constructed character, reflecting changing cultural emphases on the various meanings of childhood in recent American history. Isabelle Licari-Guillaume, for example, explores how, working within the constraints of a franchise originally devised for the promotion of a toy line, the My Little Pony: Friendship is Magic reboot was conceptualized by its creator as a platform for the promotion of a positive take on "girliness."

6 Central to such questions of adult expectations of childhood are the issues of generational media and the political child. As David Buckingham notes, childhood is "a shifting, relational term," whose opposition to adulthood "serve[s] functions not 
merely for children, but also for adults" (Buckingham 5, 10). To this extent, the creation of child-centric media helps produce or at least reiterate the adult / child divide and, as a result, serves to maintain, shape, or even transform power structures. The adult / child dichotomy is central to children's media production and reception, with the media industry and its various regulatory bodies not only addressing children and their alleged needs but also defining childhood in the process. Such is the case of the Motion Picture Association of America and the Federal Communications Commission, addressed in Adrienne Boutang's and Isabelle Licari-Guillaume's articles.

Closely related with such considerations are themes of the political child, i.e. childhood as a political construct and, more broadly, children as political agents. The presentation of children as defenceless and lacking in agency has especially been prevalent in discourses concerned with the effects of media and family values: though made in the name of children, these serve partisan purposes often specific to the adult world. The history of child-centric media is famously rife with recurring moral panics, from the dime novels of the 1870s to gangster films, comic books, rock music, roleplaying games and videogames, or anything labeled as "pornography." These controversies evidence underlying assumptions and norms about childhood-namely children's skills in interpreting media, their alleged agency (or lack thereof), as well as their place in society. While they point to conservative fears of social change (i.e. the moral corruption of imperiled children), such debates over the moral dangers of childcentric products perpetuate notions that children are largely pre-social and exposure to the media is necessarily destructive of their innocent nature. And while such discourses have obscured or neglected the role and agency of audiences (especially one as voiceless as children), they have in turn forced media producers to not only adapt their content, but also coopt theories of childhood, education, and the role of the media and cultural industries, especially with regards to their educational or socializing values. As Elena Sidorova explains in this issue, the museum world soon moved to embrace John Dewey's progressive education agenda, in the service of goals at once democratic and developmental.

8 As a testament to their overall exclusion from the political sphere (as actors, if not objects of discussion), children have most often been observed to exert agency at the micro-political level, i.e. in their private, interpersonal interactions within the home or among peers (Buckingham 13). Frequently addressed by the media as consumers, children have increasingly been considered and, allegedly, "empowered" as economic agents with growing available incomes (gifts, pocket money, paid employment) as well as a direct influence on the family's buying decisions. As early as the 1920s and 1930s, advertisers began to encourage children to nag parents-thus normalizing such behaviors as inherent to middle-class family life (Jacobson 14). Just as significantly, the deregulation of child television during the Reagan presidency was articulated in terms of kids' rights as consumers-even while Republicans' rhetoric of a war on the family presented children as an especially vulnerable group (Cook 336; Bruce 38). This suggests that despite the end of child labor, kids never truly left the economic sphere, but remained engaged in a broad range of economic activities, first as consumers, but also, increasingly, as producers of online media content. For a few decades, the child worker even coexisted alongside the child consumer, and stories of young laborers soon emerged as a favorite theme in the Gilded Age's expanding market for teen 
magazines, as Daniela Daniele shows in her discussion of Louisa May Alcott's New York tales.

9 And since the media, in the process of defining their child audiences, have generally come to segment childhood into more or less coherent age groups (or sub-varieties of them, allegedly cutting across class, race, or gender distinctions), they have contributed to the emergence and reinforcement of peer groups and peer culture. To this extent, the media drew from children's schooling in age-segregated groups, an idea introduced from Europe in the 1840s by educator Horace Mann. With the advent of more permissive child-rearing styles, as advocated in Benjamin Spock's 1946 The Common Sense Book of Baby and Child Care, post-World War Two America thus witnessed the invention and development of a "rebellious" teen culture. Musical tastes became a defining cultural and generational marker, as was well understood by the MTV cable channel, whose irreverent programming alternates between music and contents that defy the norms of the adult world. As Adrienne Boutang explains in this issue, teen culture and teen programming rest on the careful insulation of teenagers from both "children" and "adults," and the ensuing rejection of any pretensions to educational or moral uplift.

This thematic dossier's primary focus is on childhood's constructed nature and, consequently, the cultural, economic, and political conditions that have come to shape much of the child-media production. This dossier thus diverges markedly from previous policy-oriented accounts, which are primarily concerned with the influence of violence and gender stereotypes, and posit the existence of normative, universal standards for a healthy and well-lived childhood. In their efforts to deconstruct the ideological underpinnings of popular media products, such studies too often neglect the meanings effectively extracted by audiences, yet again reinforcing the myth of children's perennial innocence and cultural incompetence. In contrast, this set of essays variously emphasize the child audience's meaning-making activities as well as the media producers' roles in shaping and popularizing changing visions of childhood over time.

11 In "The Right Tone for the Hardest Moments: Louisa May Alcott's New York Stories of Child Labor and Urban Benevolence in the Mid-1870s," Daniela Daniele focuses on the tales and letters that Louisa May Alcott drew from her 1870s tour of charities for New York street boys. Alcott captured children at a pivotal moment in United States history, when they existed not only as a topic and an audience for a growing part of the country's literary production, but also as workers and consumers-a trajectory exemplified by the author, once a child worker herself. Reflecting the contradictions of philanthropic ventures quick to embrace the capitalist ethos, Alcott's depiction of children workers remains deeply ambivalent: she glosses over realities that were unpalatable to her young audience, finds children workers endearingly comic in their adult responsibilities, and, much in line with her own beliefs in uplift through hard work, embraces and legitimizes their enrollment in adult capitalist society.

Elena Sidorova's “Art Education as Social Experience: Victor D'Amico and the Origins of MoMA's Progressive Educational Project" examines curator Victor D'Amico's experiential art education programs at MoMA over the course of three decades from the 1930s to the 1960s, in the wake of earlier experiments in art education from the 1900s on. Based on the Progressive ideals promoted by the philosopher and educational reformer John Dewey, these programs were designed to foster creativity in the service 
of democracy as well as developmental objectives of self-expression and selfrealization. In their effort to give audiences an active part in art reception and art education, these initiatives represented a shift in power from previous top-down hierarchies-though they were not always successful at transcending class barriers. In "Expect the Unexpected: My Little Pony: Friendship is Magic and the Creation of a Double Audience," Isabelle Licari-Guillaume deals with Hasbro's famous franchise, whose recent reboot has allowed for a flurry of fannish activities far beyond the scope of other child-centric programs. In its newer version, the reboot's creator has sought to provide quality entertainment for girls while promoting an overt agenda-one that interrogates gender constructs, fights the stigma against "girliness," and emphasizes sisterhood. And while it was explicitly designed for co-viewing, the series has developed an unexpected, primarily adult, male audience popularly known as "bronies." Though much commented upon, the gender divide between the show's expected and actual audiences more accurately reflects "adult" modes of engagement with popular culture-often at the invitation of the series' creator, whose online interactions with fans and mastery of geek culture nurtures the show's fandom as well as maximizes fan participation.

14 Adrienne Boutang's "L'adolescence est-elle soluble dans l'enfance? Définitions et délimitations du public en littérature et culture de la jeunesse" addresses the topic of market segmentation and age segregation in youth culture, as reflected in literature, television, and film. More specifically, she addresses how producers have, from the 1930s on, worked to target a group that, to this day, remains largely undertheorized and "invisibilized": as a result of the youth culture critique's recurring use or the child / adult binary, teens have too often escaped scrutiny and remain something of a blind spot. In contrast with child-centric films, whose family appeal rests on "double address" and "crosswriting," much of teen culture deliberately excludes child and adult viewers, evincing the rise of a hyper-segmented market sanctioned by age restrictions and marked by unapologetically entertaining, rather than educational ambitions. In the process of tapping into the teen market, cultural industries have not so much coopted as created and promoted a version of teenage whose categorization into ever narrower age groups-such as tweens-now show the limitations of Hollywood's hypersegmentation strategy.

David Buckingham concludes our dossier with "Some Reflections on Children's Media Cultures: An Interview with David Buckingham." He addresses broad issues of method in child media studies (such as the too-often overlooked distinction between children's activity and agency) and offers special insights into the marketing and consumption of American child media. He especially tackles producers' efforts to satisfy both children and parents (through allegedly "pro-social" values or messages) as well as the media's role in social identity formation (for example, media use and identity performance).

In their sometimes-unrelenting promotion of toys as well as in their shaping of children's imaginations, child-centric media have come to play a major role in children's play. If, as cultural historian Johan Huizinga once wrote, "culture arises and unfolds in and as play" (i), then children have much to teach adults. The game is on. 


\section{BIBLIOGRAPHY}

BRUCE, Amanda. "Children's Media Consumption and Struggle for Cultural Authority in the Nineteenth and Twentieth Centuries." Children and Consumer Culture in American Society: A Historical Handbook and Guide. Ed. Lisa Jacobson. Westport: Praeger, 2008, p. 3-25.

BUCKINGHAM, David. After the Death of Childhood: Growing Up in the Age of Electronic Media. Cambridge: Polity Press, 2000.

COOK, Daniel Thomas. "Children as Consumers." The Palgrave Handbook of Childhood Studies. Eds. Jen Qvotrup, William A. Caroso, and Michael-Sebastian Honig. London: Palgrave Macmillan, 2009 , p. 332-347.

DECORDOVA, Richard. "The Mickey in Macy's Window: Childhood, Consumerism, and Disney Animation." Disney Discourse: Producing the Magic Kingdom. Ed. Eric Smoodin. New York: Routledge, 1994, p. 203-212.

HUIZINGA, Johan. Homo Ludens: A Study of the Play-Element in Culture. 1949. London: Routledge, 1980.

JACOBSON, Lisa. "Advertising, Mass Merchandising, and the Creation of Children's Consumer Culture." Children and Consumer Culture in American Society: A Historical Handbook and Guide. Westport: Praeger, 2008, p. 3-25.

JAMES, Allison, and Alan PROUT. "A New Paradigm for the Sociology of Childhood? Provenance, Promise, and Problems." Constructing and Reconstructing Childhood. Eds. Allison James and Alan Prout. London: Falmer Press, 1990, p. 7-34.

JAMES, Allison, and Alan PROUT. "Introduction." Constructing and Reconstructing Childhood. Eds. Allison James and Alan Prout. London: Falmer Press, 1990, p. 1-6.

"Much Apu about Nothing." The Simpsons, season 7 episode 23. Created by Matt Groening. Written by David S. Cohen. Directed by Susie Dietter. With Maggie Roswell (Helen Lovejoy). Fox, May 1996.

QVOTRUP, Jen. "Placing Children in the Division of Labor." Family and Economy in Modern Society. Eds. Rosemary Collins and Paul Close. Basingstoke: Macmillan, 1985, p. 129-145.

ZELIZER, Viviana A. Pricing the Priceless Child: The Changing Social Value of Children. Princeton: Princeton University Press, 1994.

\section{ABSTRACTS}

An introduction to the thematic dossier, this contribution situates the emergence of child-media in the larger history of the media in the United States. After raising the question of the place assumed by children, teenagers, and young adults in the media system that targets them, as well as the roles they get to play in it, this introduction presents the contributions in the dossier.

Cette introduction au dossier thématique replace la question de l'émergence de médias à destination des enfants dans le temps plus long de l'histoire des médias aux États-Unis. L'introduction interroge la place et le rôle des enfants, des adolescents et des jeunes adultes dans l'écosystème médiatique destiné à l'enfance et à la jeunesse, avant de présenter les contributions qui composent le dossier. 
INDEX

Mots-clés: enfance, jeunesse, médias, États-Unis

Keywords: childhood, youth, media, United States

\section{AUTHOR}

\section{THIBAUT CLÉMENT}

Sorbonne Université 